\title{
PENERAPAN PROCESS-ORIENTED GUIDED INQUIRY LEARNING (POGIL) UNTUK MENINGKATKAN KETERAMPILAN GENERIK SAINS DAN PRESTASI BELAJAR SISWA PADA MATERI LARUTAN PENYANGGA
}

\author{
Hening Asti Rahayu, Ashadi* dan Suryadi Budi Utomo \\ Program Studi Pendidikan Kimia, FKIP, Universitas Sebelas Maret, Surakarta, Indonesia \\ *Keperluan korespondensi, telp : +628-16671690, email : ashadi_uns@yahoo.com
}

\begin{abstract}
ABSTRAK
Penelitian ini bertujuan untuk meningkatkan: (1) keterampilan generik sains siswa menggunakan model pembelajaran Process Oriented Guided Inquiry Learning (POGIL); (2) prestasi belajar siswa pada materi pokok bahasan larutan penyangga di kelas XI MIPA 4 SMA Negeri 5 Surakarta melalui model pembelajaran Process Oriented Guided Inquiry Learning (POGIL). Penelitian ini merupakan penelitian tindakan kelas yang terdiri atas 2 siklus. Pada setiap siklus terdiri atas tahap perencanaan, pelaksanaan, observasi dan refleksi. Subjek penelitian adalah siswa kelas XI MIPA 4 SMA Negeri 5 Surakarta. Teknik pengumpulan data dengan cara tes, angket, observasi, kajian dokumen dan wawancara, analisis data menggunakan teknik analisis deskriptif kualitatif. Berdasarkan hasil penelitian disimpulkan bahwa pengaplikasian model pembelajaran Process Oriented Guided Inquiry Learning (POGIL) dapat meningkatkan: (1) keterampilan generik sains pada materi larutan penyangga. Hal tersebut terlihat pada kenaikan prasiklus sebesar $39 \%$ menjadi $71 \%$ pada siklus I dan $87 \%$ pada siklus II. (2) Prestasi belajar siswa pada materi larutan penyangga (aspek pengetahuan $29 \%$ pada siklus I dan meningkat menjadi $77 \%$ pada siklus II, aspek sikap ketercapaian siswa yaitu $100 \%$ dimana $29 \%$ pada kategori Baik dan $71 \%$ pada kategori Sangat Baik, sedangkan pada aspek keterampilan juga telah mencapai ketercapaian maksimum yaitu $100 \%$ dimana rata-rata ketercapaian indikator keterampilannya yaitu $88,5 \%)$.
\end{abstract}

Kata Kunci: Process Oriented Guided Inquiry Learning (POGIL), Keterampilan Generik Sains, Prestasi Belajar, Larutan Penyangga.

\section{PENDAHULUAN}

Pendidikan merupakan salah satu bagian penting bagi kemajuan bangsa, dimana dengan pendidikan potensi diri dan cara berfikir individu akan meningkat. Suatu sistem pendidikan yang baik diharapkan dapat mencetak generasigenerasi penerus bangsa yang dapat memajukan negaranya, dalam hal ini yaitu Negara Kesatuan Republik Indonesia. Hal tesebut selaras dengan pengertian pendidikan Pasal 1 UU Nomor 20 Tahun 2003 yang menyatakan bahwa pendidikan adalah usaha sadar dan terencana untuk mewujudkan suasana

belajar dan proses pembelajaran agar peserta didik secara aktif mengem- bangkan potensi dirinya untuk memiliki kekuatan spiritual keagamaan, pengendalian diri, kepribadian, kecerdasan, akhlak mulia, serta keterampilan yang diperlukan dirinya, masyarakat, bangsa dan negara. Sistem Pendidikan Nasional adalah keseluruhan komponen pendidikan yang saling terkait secara terpadu untuk mencapai tujuan pendidikan [1]. Sistem pendidikan di Indonesia senantiasa diperbarui guna peningkatan potensi peserta didik secara maksimal. Salah satu upaya yang dilaksanakan oleh pemerintah Indonesia untuk mencapai peningkatan tersebut adalah dengan penerapan kurikulum, sistem dan metode baru dalam pembelajaran. 
Undang-Undang nomor 20 Tahun 2003 tentang Sistem Pendidikan Nasional menyebutkan bahwa kurikulum mengandung dua dimensi: (1) rencana dan pengaturan mengenai tujuan, isi, dan bahan pelajaran. (2) cara yang digunakan untuk kegiatan pembelajaran. Kurikulum pendidikan yang berlaku saat ini adalah kurikulum 2013. Kurikulum 2013 yang diberlakukan mulai tahun ajaran 2013/2014 memenuhi kedua dimensi tersebut.

Kurikulum 2013 yang berdasarkan kompetensi dan karakter memiliki tujuan dan harapan ingin mengubah pola pendidikan dari orientasi terhadap hasil dan materi ke pendidikan sebagai proses, melalui suatu pendekatan tematik integratif dengan contextual teaching and learning (CTL) [2]. Oleh sebab itu, pembelajaran harus sebanyak mungkin melibatkan peserta didik, agar mereka mampu bereksplorasi untuk membentuk kompetensi dengan menggali berbagai potensi, dan kebenaran secara ilmiah. Salah satu cara guna mencapai tujuan tersebut dalam pembelajaran kimia, terutama pada penerapan kurikulum 2013 yaitu menerapkan model pembelajaran yang sesuai dengan Permendikbud Nomor 65 Tahun 2013 tentang Standar Proses menyebutkan bahwa model yang diutamakan pada implementasi Kurikulum 2013 adalah model pembelajaran inquiry, discovery learning, project based learning, dan problem based learning.

Pada kurikulum 2013 juga sudah dirujuk model-model pembelajaran yang sesuai dengan kegiatan pembelajaran kurikulum 2013 dimana kegiatan pembelajaran sepenuhnya diarahkan pada pengembangan melalui pendekatan saintifik dan diperkuat dengan penerapan pembelajaran berbasis penelitian yaitu inquiry [3]. Penggunaan model inkuiri dapat meningkatkan pembelajaran kimia [4]. Proses inkuiri bertujuan menumbuhkan kemampuan berpikir, bekerja, dan bersikap ilmiah serta berkomunikasi sebagai salah satu aspek penting kecakapan hidup.

Model pembelajaran yang dipilih pada penelitian ini adalah Process Oriented Guided Inquiry Learning
(POGIL). POGIL merupakan penyempurnaan dari inkuiri terbimbing yang dapat mempermudah pelaksanaan pembelajaran secara inkuiri baik dikelas maupun di laboratorium [3]. Pembelajaran dengan model POGIL mengutamakan penyelidikkan dalam menemukan konsep pada proses pembelajaran sehingga berpusat pada aktivitas siswa (student centered). Proses pembelajaran POGIL menggunakan kegiatan yang dirancang khusus dan pembelajaran kooperatif untuk mengajar konten secara aktif melibatkan para siswa dalam penyelidikan, berpikir analitis dan kerja sama tim sehingga keterampilan proses dan keterampilan generik siswa semakin berkembang [5]. Pembelajaran berbasis inquiry bertujuan untuk mendorong siswa semakin berani dan kreatif dalam berimajinasi, sehingga siswa dapat menciptakan penemuanpenemuan, baik dari yang pernah ada maupun menciptakan ide, gagasan, atau alat yang belum pernah ada sebelumnya [6].

Tingkat tinggi-rendahnya peranan keaktifan peserta didik dalam proses belajar mengajar sangat penting, khususnya pada mata pelajaran kimia. Salah satu materi dalam pembelajaran kimia yang membutuhkan tingkat pemahaman lebih adalah larutan penyangga, konsep yang kompleks dan abstrak menyebabkan siswa beranggapan bahwa larutan penyangga merupakan salah satu materi kimia yang sulit [7]. Hal tersebut juga didukung oleh penelitian Murti (2014) dan Kurniawan (2014) bahwa materi pokok larutan penyangga merupakan materi yang memerlukan pemahaman konsep kompleks dan kemampuan matematika untuk perhitungan kimia, dimana akan digunakan sebagai dasar dalam mempelajari materi selanjutnya [8][9].

Pada proses pembelajaran partisipasi peserta didik dengan prestasi yang diraih memiliki keterkaitan. Masih rendahnya partisipasi peserta didik menyebabkan prestasi akademik yang diperoleh pun rendah. Termasuk SMA N 5 Surakarta pada pelajaran kimia materi larutan penyangga, terbukti dengan hasil persentase penguasaan materi soal kimia Ujian Nasional yang dapat dikatakan masih rendah. Berikut disajikan data 
presentase nilai pada penguasaan materi larutan penyangga di SMA N 5 Surakarta pada 3 tahun berturut-turut ujian nasional, data disajikan pada Tabel 1.

Tabel 1. Persentase Penguasaan Materi Soal Kimia Ujian Nasional SMA N 5 Surakarta (Kemampuan yang diuji: Mendeskripsikan sifat larutan penyangga)

\begin{tabular}{ccc}
\hline $\begin{array}{c}\text { Tahun } \\
\text { Pelajaran }\end{array}$ & $\begin{array}{c}\text { Nilai } \\
\text { Sekolah }\end{array}$ & Nasional \\
\hline $2013 / 2014$ & 37,41 & 56,97 \\
$2014 / 2015$ & 74,80 & 63,95 \\
$2015 / 2016$ & 57,67 & 47,20 \\
\hline
\end{tabular}

Pada Tabel 1. terlihat bahwa penguasaan materi larutan penyangga pada tahun 2014 diperoleh persentase nilai sebesar 37,41 ; hasil tersebut lebih rendah 19,56 dibandingkan dengan nilai secara nasional. Pada tahun 2015 mengalami peningkatan yakni sebesar 74,80 ditingkat sekolah dan 63,95 ditingkat nasional, meskipun telah mengalami peningkatan namun nilai tersebut masih dikategorikan rendah. Kemudian ditahun 2016 persentase perolehan nilai UN rata-rata pada materi larutan penyangga di tingkat sekolah maupun nasional mengalami penurunan dibandingkan tahun sebelumnya yakni menjadi 57,67 di tingkat sekolah dan 47,20 ditingkat nasional. Hal tersebut dapat dikatakan bahwa perolehan nilai peserta didik SMA N 5 Surakarta pada materi pokok Larutan Penyangga dapat dikatakan masih rendah. Oleh karena itu, materi larutan penyangga sebagai objek penelitian ini.

Salah satu keterampilan siswa yang tak pernah lepas pada setiap materi kimia disekolah adalah keterampilan generik sains. Keterampilan generik sains merupakan suatu kemampuan dasar yang bersifat umum dan dapat dikembangkan melalui proses pembelajaran konsep-konsep kimia [10]. Keterampilan generik menjadi suatu hal yang penting dan bersifat umum, karena implementasinya memberikan kesuksesan sesuai dengan bidang masing-masing khususnya dalam bidang sains [11].
Kemampuan generik tidak didapatkan secara tiba-tiba melainkan keterampilan tersebut harus dilatih terus menerus agar terjadi peningkatan [12]. Keterampilan generik dibagi dalam dua kelompok besar, yakni keterampilan dasar dan keterampilan kunci yang lebih luas. Keterampilan kunci yang lebih luasnya meliputi kerjasama, komunikasi dan keterampilan manajemen informasi, etika kesadaran dan praktek, integritas dan toleransi, berpikir kritis, pemecahan masalah, keterampilan interpersonal, kapasitas untuk berpikir logis dan independen, rasa ingin tahu intelektual dan ketelitian, kreativitas [13].

Berkembangnya keterampilanketerampilan siswa seperti mengamati, berpikir kritis, berkomunikasi, memecahkan masalah dan menyimpulkan data merupakan salah satu wujud dari kemampuan berinkuiri. Upaya yang dapat dilakukan pada pembelajaran untuk peningkatan prestasi belajar dan keterampilan generik sains yaitu dengan penyesuaian model pembelajaran dan karakteristik siswa, salah satu pembelajaran yang dapat meningkatkan kemampuan berpikir dan pemecahan masalah adalah POGIL. Proses kegiatan belajar mengajar (KBM) untuk mata pelajaran kimia oleh guru di SMA N 5 Surakarta cenderung guru yang lebih dominan dalam pembelajaran sedangkan siswa bersifat pasif. Dominannya guru dalam proses belajar mengajar mengakibatkan potensi-potensi yang dimiliki siswa seperti keterampilan dasar (generik) siswa tidak berkembang secara optimal. Keterampilan generik sains diperlukan siswa untuk mempelajari berbagai konsep dan menyelesaikan berbagai masalah sains misalnya pada materi larutan penyangga.

Faktor-faktor yang mempengaruhi prestasi belajar siswa yang di teliti dalam penelitian ini antara lain model pembelajaran dan keterampilan generik sains. Dalam hal ini, model pembelajaran merupakan salah satu contoh dari faktor eksternal, sedangkan keterampilan generik sains merupakan faktor internal yang mempengaruhi keberhasilan prestasi belajar siswa. 
Berdasarkan penjelasan di atas, maka perlu di terapkan model pembelajaran yang mampu menyajikan kompetensi dasar yang ingin di capai dengan maksimal. Dengan demikian materi larutan penyangga sesuai apabila di implementasikan menggunakan model pembelajaran Process Oriented Guided Inquiry Learning (POGIL) yang melibatkan keterampilan generik sains di dalamnya. Adanya pengaplikasian model pembelajaran POGIL ini, diharapkan terdapat peningkatan prestasi belajar dan keterampilan generik sains siswa pada materi larutan penyangga. Berdasarkan latar belakang diatas maka disusunlah penelitian dengan judul "Pengaplikasian Model Pembelajaran Process Oriented Guided Inqury Learning (POGIL) untuk Meningkatkan Keterampilan Generik Sains dan Prestasi Belajar Siswa Pada Materi Larutan Penyangga Kelas XI MIPA SMA N 5 Surakarta Tahun Pelajaran 2017/2018".

\section{METODE PENELITIAN}

Metode penelitian yang digunakan adalah metode penelitian tindakan kelas (PTK) yang dilaksanakan dua siklus, dan setiap siklus terdiri atas empat tahapan yaitu perencanaan penelitian, pelaksanaan tindakan, observasi dan refleksi.

\section{Tempat dan Waktu Penelitian}

Penelitian ini dilaksanakan di SMA Negeri 5 Surakarta kelas XI MIPA pada semester genap tahun pelajaran 2017/2018 yang beralamat di Jalan Letnan Jendral Sutoyo 18 Surakarta, Jawa Tengah. Pelaksanaan penelitian yakni bulan Maret-April 2018.

\section{Subjek dan Objek Penelitian}

Subjek dalam penelitian ini adalah siswa kelas XI MIPA 4 semester genap SMA Negeri 5 Surakarta tahun pelajaran 2017/2018. Sedangkan, objek penelitiannya adalah keterampilan generik sains dan prestasi belajar siswa terhadap pembelajaran yang diterapkan pada materi larutan penyangga.
3. Data, Sumber Data dan Teknik Pengumpulan Data

Data penelitian yang dikumpulkan merupakan data aspek kualitatif yang meliputi data hasil observasi dan wawancara dengan guru maupun siswa yang menggambarkan proses pembelajaran dikelas, sedangkan aspek kuantitatif adalah penilaian pada keterampilan generik sains dan prestasi belajar siswa.

Sumber data yang digunakan dalam penelitian ini adalah responden (guru dan siswa) dan dokumen (silabus, RPP, arsip UAS semester 1 XI MIPA 4). Sedangkan pengumpulan data yang dilakukan pada penelitian ini adalah dengan teknik tes dan non-tes

4. Teknik Uji Validitas Data dan Reliabilitas Instrumen

Instrumen dalam penelitian ini meliputi instrumen pembelajaran dan instrumen penialian. Uji validitas instrumen menggunakan formula Gregory, sedangkan uji reliabilitas menggunakan aplikasi ITEMAN dan atau aplikasi SPSS.

\section{Teknik Analisis Data}

Data-data dari hasil penelitian di lapangan diolah dan dianalisis secara kualitatif. Teknik analisis data secara kualitatif mengacu pada model analisis [14], yakni analisis yang dilakukan dalam tiga komponen yaitu reduksi data, penyajian data, dan penarikan kesimpulan dan verifikasi.

\section{Indikator Kinerja Penelitian}

Indikator kinerja merupakan rumusan kinerja sebagai tolak ukur keberhasilan atau keefektifan penelitian yang dilakukan [15]. Indikator kinerja penelitian ini disesuaikan dengan kemampuan rata-rata siswa yaitu sebesar 70 (apek pengetahuan), 75 (aspek sikap, ketrampilan dan keterampilan generik sains). Indikator capaian tersebut digambarkan sesuai pada Tabel 2. berikut ini. 
Tabel 2. Rubrik Kinerja Penilaian

\begin{tabular}{lc}
\hline Aspek yang diukur & $\begin{array}{c}\text { Persentase } \\
\text { Ketuntasan Siswa } \\
\text { Siklus I (\%) }\end{array}$ \\
\hline Pengetahuan & 70 \\
Sikap & 75 \\
Keterampilan & 75 \\
Keterampilan & 75 \\
Generik Sains & \\
\hline
\end{tabular}

\section{Prosedur Penelitian}

Prosedur penelitian tindakan kelas ini terdiri atas empat tahapan, yaitu : (1) Tahap perencanaan penelitian yang merupakan tahap persiapan perangkat pembelajaran seperti RPP, modul, alat dan bahan serta perangkat/ instrumen penilaian. (2) Tahap pelaksanaan tindakan merupakan tahapan pelaksanaan pembelajaran dengan model POGIL sesuai dengan rencana dalam RPP. (3) Tahap observasi atau pengamatan merupakan tahapan dimana sikap dan keterampilan siswa dinilai oleh observer. (4) Tahap refleksi merupakan tahap untuk analisis respon peserta didik, pencocokan hasil pengamatan observer dan pengidentifikasian kembali hasil tindakan dalam penelitian.

\section{HASIL DAN PEMBAHASAN}

Penelitian tindakan kelas yang dilakukan pada kelas XI MIPA 4 SMA Negeri 5 Surakarta tahun pelajaran $2017 / 2018$ terdiri atas dua siklus. Siklus I dilaksanakan dalam empat kali pertemuan. Sedangkan di siklus II dilaksanakan dua kali pertemuan. Evaluasi akhir pada siklus I dan siklus II meliputi tes pengetahuan materi larutan penyangga dan tes aspek KGS.

\section{Siklus I}

Perencanaan tindakan siklus I meliputi penyusunan instrumen pembelajaran dan instrumen penilaian. Instrumen pembelajaran tersebut adalah silabus, RPP, dan media pembelajaran yaitu LKS. Sedangkan instrumen penilaiannya adalah penilaian aspek pengetahuan, sikap, keterampilan dan keterampilan generik sains siswa.

Pelaksanaan pembelajaran dilakukan dengan setiap pertemuan $2 \times 45$ menit.
Pertemuan pertama merupakan pembahasan pada pokok materi terkait definisi larutan penyangga, membedakan larutan penyangga dan bukan penyangga serta sifat larutan penyangga. Pertemuan kedua pembahasan pada penghitungan $\mathrm{pH}$ atau $\mathrm{pOH}$ larutan penyangga, sedangkan pertemuan ketiga membahas tentang pengaruh penambahan asam/basa/air pada $\mathrm{pH}$ larutan penyangga dan fungsi larutan penyangga bagi makhluk hidup. Pada setiap pertemuan dilaksanakan penilaian aspek sikap dan di akhir dilakukan penilaian keterampilan presentasi siswa. Hasil penilaian tindakan selama siklus I dirangkum dalam Tabel 3.

Tabel 3. Hasil Penilaian Prestasi Belajar dan Keterampilan Generik Sains Siklus I

\begin{tabular}{lcc}
\hline $\begin{array}{c}\text { Aspek yang } \\
\text { dinilai }\end{array}$ & $\begin{array}{c}\text { Ketercapaian } \\
(\%)\end{array}$ & Kriteria \\
\hline Pengetahuan & 29 & BT \\
Sikap & 100 & T \\
Keterempilan & 100 & T \\
KGS & 71 & BT \\
\hline
\end{tabular}

${ }^{*} T$ : Tercapai, BT : Belum Tercapai

Berdasarkan Tabel 3, aspek yang belum tercapai sesuai dengan target ketuntasan adalah aspek pengetahuan dan keterampilan generik sains. Pada aspek pengetahuan, ketuntasan yang tercapai pada siklus I ini sebesar $29 \%$. Berdasarkan presentase ketercapaian tiap indikator soal, bahwa masih terdapat 17 indikator soal yang belum memenuhi target ketercapaian. Berdasarkan hasil analisis dan wawancara dengan siswa, menyebutkan bahwa siswa masih kurang teliti dan sedikit bingung ketika menghitung $\mathrm{pH} / \mathrm{pOH}$ larutan penyangga. Selain itu, ketika proses diskusi berlangsung masih ada beberapa siswa yang tidak mau untuk bertanya ke guru maupun teman ketika menjumpai kesulitan, sehingga bagian-bagian materi yang membutuhkan pemahaman lebih dalam, sukar untuk dimengerti oleh siswa.

Pada aspek keterampilan generik sains, ketuntasan siswa adalah sebesar $71 \%$. Selama proses pembelajaran di siklus I, masih ada beberapa siswa yang pasif dalam kelompok diskusi, tidak 
memperhatikan penjelasan guru, tidak ikut serta terlibat dalam proses diskusi yang dapat meningkatkan keterampilan berpikir kritis dan ada juga siswa yang memilih untuk tidur pada saat diskusi kelompok berlangsung. Hal-hal tersebut tentu saja mempengaruhi tingkat keterampilan generik sains siswa tersebut.

Pada penilaian aspek sikap (spiritual dan sosial) dan aspek keterampilan siswa sudah mencapai target yang ditentukan, yakni dengan ketercapaian sebesar $100 \%$ untuk aspek sikap dan $100 \%$ untuk aspek keterampilan. Pada siklus II tidak diadakan lagi penilaian terhadap aspek sikap maupun keterampilan, karena target telah tercapai.

Berdasarkan keseluruhan hasil yang diperoleh pada siklus I dimana aspek pengetahuan dan keterampilan generik sains belum mencapai target ketuntasan, maka dari itu perlu dilakukan tindakan lebih lanjut yaitu dengan melakukan pembelajaran siklus II guna meningkatkan dan memperbaiki kekurangan pada pembelajaran di siklus I. Selama proses refleksi, terdapat beberapa rekomendasi untuk dijadikan bahan pertimbangan perbaikan pada tindakan di siklus II yang meliputi perubahan jumlah anggota kelompok dan juga perubahan konten pada LKS pembelajaran.

\section{Siklus II}

Tindakan pada siklus II lebih difokuskan untuk penyempurnaan serta perbaikan terhadap masalah-masalah yang terdapat pada siklus I. Oleh sebab itu, pada siklus II guru lebih menekankan pada latihan soal yang di diskusikan dalam kelompok kecil saja, sehingga diskusi dapat lebih bermakna. Pada tahap perencanaan guru bersama peneliti merencanakan untuk memperbarui konten LKS pada siklus II agar dapat lebih mudah dipahami oleh siswa. Kemudian membuat RPP POGIL siklus II. Sedangkan untuk aspek keterampilan generik sains, instrumen yang digunakan masih dengan butir soal yang sama namun penomorannya diacak.

Pelaksanaan tindakan pada siklus II dilakukan dengan 1 kali pertemuan (2x45 menit) untuk mengulang materi dengan memfokuskan pada indikator yang belum mencapai target ketuntasan. Kemudian 1 kali pertemuan untuk evaluasi siklus II. Adapun rangkuman hasil penilaian tindakan selama siklus II terdapat pada Tabel 4.

Tabel 4. Hasil Penilaian Siklus II

\begin{tabular}{lcc}
\hline $\begin{array}{c}\text { Aspek yang } \\
\text { dinilai }\end{array}$ & $\begin{array}{c}\text { Ketercapaian } \\
(\%)\end{array}$ & Kriteria \\
\hline Pengetahuan & 77 & Tercapai \\
$\begin{array}{l}\text { Keterempilan } \\
\text { Generik }\end{array}$ & 87 & Tercapai \\
Sains & & \\
\hline
\end{tabular}

Berdasarkan hasil target ketercapaian dari kedua aspek pada siklus II yang disajikan Tabel 4, dapat disimpulkan bahwa pelaksanaan model pembelajaran POGIL di kelas XI MIPA 4 SMA Negeri 5 Surakarta pada materi larutan penyangga ini telah berhasil. Penelitian tindakan kelas ini diakhiri pada siklus II karena prestasi belajar dan keterampilan generik sains yang diukur telah mencapai target yang ditentukan.

\section{Perbandingan Hasil Tindakan Antarsiklus}

\section{a. Keterampilan Generik Sains}

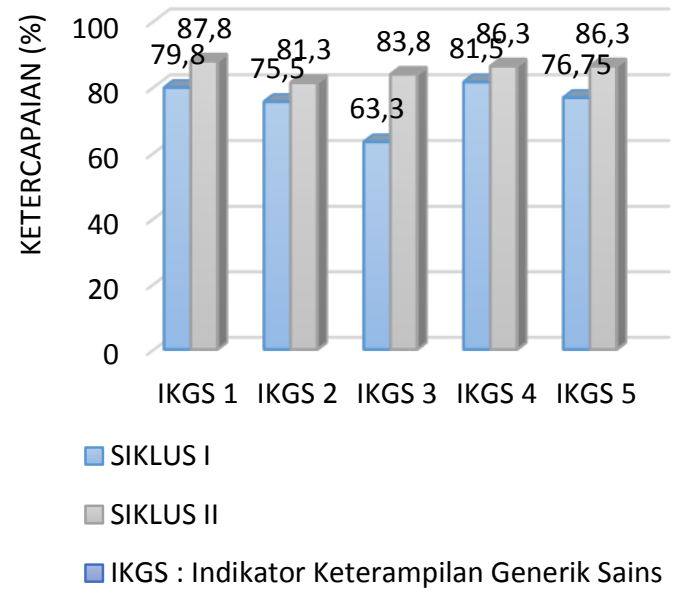

Gambar 1. Histogram Peningkatan Ketuntasan Indikator Keterampilan Generik Sains

Berdasarkan Gambar 1, terlihat bahwa terdapat peningkatan disetiap indikator KGS. Indikator KGS tersebut secara berturut meliputi : menyelesaikan masalah, berpikir kritis, menganalisis, 
komunikasi dan kerjasama. Secara keseluruhan hasil ketuntasan KGS siswa disajikan dalam Gambar 2.

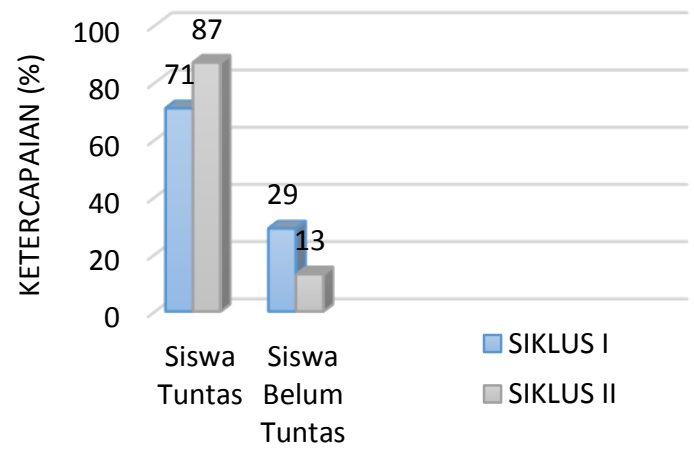

Gambar 2. Histogram Peningkatan Ketuntasan Keterampilan Generik Sains

Gambar 2, menunjukkan bahwa selama dilakukan tindakan pada siklus II keterampilan generik sains siswa dapat meningkat secara signifikan yaitu dari $71 \%$ menjadi $87 \%$. Peningkatan tersebut disebabkan oleh beberapa faktor, yaitu : (1) Adanya penerapan model POGIL yang tahap-tahap pembelajarannya menunjang indikator-indikator pada keterampilan generik sains siswa. Melalui tahaptahap pembelajaran POGIL, siswa dilatih untuk aktif dalam berpikir secara sains, hal tersebut dilakukan pada tahap menghubungkan pengetahuan sebelumnya, eksplorasi, pemahaman dan pembentukan konsep. Selain itu, siswa juga akan terampil untuk dapat menyelesaikan masalah sains, hal tersebut dilakukan pada tahap pembelajaran pemahaman dan pembentukan konsep, mengaplikasikan pengetahuan ke dalam konteks baru. Kerjasama siswa pun akan meningkat ketika siswa diminta untuk melakukan presentasi dan juga ketika berdiskusi.

Hal tersebut juga sesuai dengan penelitian yang dilakukan oleh Febriyanti (2014) yang menyatakan bahwa model pembelajaran berbasis inquiry dan problem solving dapat meningkatkan keterampilan generik sains siswa pada indikator kerjasama dan pemecahan masalah [16]. Disisi lain juga dengan adanya latihan soal baik mandiri maupun kelompok akan menumbuhkan sikap positif siswa terhadap sains, sehingga keterampilan generik sains siswa pun akan meningkat. Pada pembelajaran POGIL yang berlangsung, siswa selalu disajikan dengan suatu masalah sains terutama pada kimia materi larutan penyangga dan juga siswa dilibatkan dalam pemecahan masalah sains tersebut. Proses pemecahan masalah tersebut selalu dilakukan disetiap pertemuan dalam setiap kelompok diskusi masing-masing. Sehingga seiring berjalannya waktu, siswa menjadi terbiasa untuk berpikir lebih kritis dan kemudian mengkomunikasikan dengan sesama anggota kelompoknya, hal tersebut tentunya akan meningkatkan keterampilan generik sains siswa. Hal ini sesuai dengan penelitian dalam jurnal yang ditulis oleh Hande \& Kommattil (2015) yang menjelaskan bahwa pembelajaran berbasis masalah dapat menghasilkan peningkatan pengetahuan, keterampilan generik sains dan sikap [17].

Mercer-mapstone \& Kuchel (2016) juga menyebutkan bahwa pembelajaran dengan pendekatan praktik secara langsung (presentasi, diskusi, pengisian lembar kerja individu /kelompook) dan berbasis bukti akan meningkatkan keterampilan generik sains khususnya keterampilan komunikasi. Disisi lain Curtis \& Denton (2003) juga menyarankan hal yang sama bahwa apabila ingin meningkatkan keterampilan generik sains, maka pendekatan pembelajaran yang digunakan sebaiknya adalah pembelajaran berbasis pemecahan masalah dan/atau penyajian masalah sehingga siswa akan diajak untuk menemukan pengetahuannya sendiri.

Peningkatan keterampilan generik sains siswa disebabkan oleh faktor selanjutnya yaitu : (2) Adanya penggunaan media tambahan berupa penggunaan LKS larutan penyangga yang telah disusun berbasiskan inkuiri. Pada LKS tersebut telah disusun dengan format yang membuat siswa mampu menemukan konsep pengetahuan dengan disertai sedikit bimbingan oleh guru, sehingga akan mendorong terjadinya student centered learning. Adanya penggunaan LKS ini juga mendorong siswa untuk aktif dalam berpikir secara kritis, terbiasa menganalisis masalah dan memecahkan masalah bersama dengan 
kelompoknya. Oleh karena itu, siswa tidak hanya menghafal materi ataupun rumus saja melainkan siswa juga paham akan konsep dalam pembelajaran.

\section{b. Prestasi Belajar}

Menurut kurikulum 2013, penilaian aspek prestasi belajar meliputi 3 aspek, yaitu aspek pengetahuan, sikap dan keterampilan. Pada Gambar 3. disajikan ketercapaian ketuntasan siswa pada aspek pengetahuan siklus I dan II.

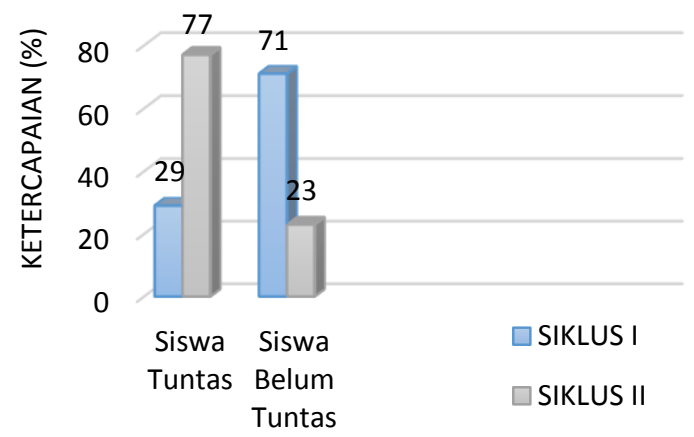

Gambar 3. Histogram Peningkatan Ketuntasan Belajar Sikluss I dan II

Berdasarkan Gambar 3. Ketercapaian hasil dari tes pengetahuan pada siklus I yaitu $29 \%$. Pada 25 indikator soal yang diberikan, masih terdapat 17 indikator soal yang belum mencapai target ketuntasan, sehingga diperlukan tindakan siklus II. Sedangkan, hasil ketercapaian aspek pengetahuan pada siklus II yaitu $77 \%$.

Peningkatan ketercapaian pada aspek pengetahuan tersebut dikarenakan oleh beberapa faktor, yaitu : (1) materi yang disampaikan lebih difokuskan pada indikator materi yang belum mencapai target ketuntasan. (2) Adanya perubahan pada pembagian kelompok menjadi sebuah kelompok kecil, dimana dalam setiap kelompok terdapat perwakilan siswa yang telah tuntas pada evaluasi siklus I, sehingga mereka dapat membantu teman dalam satu kelompoknya dan pembelajaran yang berlangsung menjadi lebih bermakna. (3) Perubahan konten dalam LKS yang lebih mempermudah siswa untuk memahami materi. (4) Latihan soal-soal yang diberikan berasal dari soal evaluasi pada siklus I. Hal-hal tersebut yang menyebabkan adanya peningkatan presentase keter- capaian ketuntasan belajar siswa yang cukup signfikan.

Aspek prestasi belajar selanjutnya adalah aspek sikap. Penilaian sikap siswa dilakukan dengan mengukur sikap spiritual dan sosial (jujur, disiplin, tanggungjawab dan kerjasama). Pengukuran aspek sikap dilakukan dengan observasi dan angket diri serta wawancara jika terjadi ketidaksesuaian. Pencapaian rata-rata indikator aspek sikap pada siklus I sudah mencapai target ketuntasan yaitu sebesar 90,9\%, sedangkan pencapaian ketuntasan aspek sikap yaitu sudah $100 \%$ dimana meliputi $71 \%$ dengan kategori Sangat Baik dan $29 \%$ dengan kategori Baik. Pada pengukuran aspek sikap di siklus I yang sudah dikatakan baik dan mencapai target ketuntasan sehingga pada siklus II tidak dilakukan pengukuran kembali pada aspek sikap.

Aspek prestasi belajar yang ketiga adalah aspek keterampilan. Penilaian aspek keterampilan yaitu melalui keterampilan presentasi siswa yang dilakukan pada siklus I. Indikator yang dinilai dalam presentasi yaitu kerjasama, komunikasi verbal, penyampaian, penampilan dan isi presentasi. Target yang ditetapkan pada aspek keteram-pilan adalah sebesar $75 \%$. Ketercapaian ratarata indikator aspek keterampilan yang dinilai pada siklus I sudah mencapai $88,5 \%$ dan ketuntasan siswa yaitu $100 \%$.

Beradasarkan pencapaian hasil dari ketiga aspek prestasi belajar, dapat disimpulkan bahwa pembelajaran POGIL dapat meningkatkan prestasi belajar siswa. Hal ini sejalan dengan penelitian Maulidiawati (2014) yang membuktikan bahwa pembelajaran POGIL dapat meningkatkan prestasi belajar siswa secara signifikan [18]. Hal tersebut juga sesuai dengan hasil penelitian yang dilakukan oleh Indraswari, Widodo \& Muchlis (2015) dimana keterlaksanaan model pembelajaran POGIL berlangsung efektif dan dapat meningkatkan skor rata-rata penilaian keterlaksanaan pembelajaran dalam setiap pertemuan. Pembelajaran dengan model POGIL dapat memberikan efek yang positif bagi prestasi belajar siswa [4]. Hasil dari penelitian tindakan kelas ini juga selaras 
dengan kesimpulan penelitian oleh Kori, Mäeots \& Pedaste (2014) yang menyarankan, apabila ingin meningkatkan keterampilan inkuiri (menemukan), prestasi belajar siswa dan membuat pembelajaran lebih bermakna maka terapkan model pembelajaran berbasis inkuiri yang terbimbing dan mengintegrasikannya dengan teknologi lingkungan belajar [19]. Peneliti lain yang juga berpendapat model POGIL akan meningkatkan prestasi belajar siswa yaitu Şen \& Yılmaz (2015) menyebutkan dari hasil penelitiannya bahwa POGIL meningkatkan pengetahuan siswa, sikap siswa, keterampilan berpikir kritis, kemampuan inkuiri, kemandirian, kemampuan manajemen waktu dan manajemen lingkungan [20].

Hasil penelitian juga sejalan dengan teori belajar Bruner yang mengungkapkan bahwa dalam pembelajaran siswa harus aktif untuk melakukan penemuan konsepnya sendiri. Pengetahuan yang didapatkan oleh penemuannya sendiri akan lebih dipahami oleh siswa, sehingga akan berdampak pada peningkatan prestasi belajar siswa. Pembelajaran secara POGIL terbukti dapat meningkatkan keterampilan generik sains dan prestasi belajar siswa, karena dalam proses pembelajarannya siswa selalu disajikan dengan suatu permasalahan sains yang harus dipecahkan secara kritis dan analis baik individu maupun kelompok. Disisi lain hasil penelitian ini juga sesuai dengan teori belajar Piaget, ketika proses pembelajaran dan diskusi siswa juga akan menjadi pribadi yang lebih aktif karena adanya suatu permasalahan sains yang harus didiskusikan bersama, sehingga pembelajaran yang terjadi menjadi lebih bermakna sesuai dengan teori belajar bermakna yang dikemukakan oleh Ausubel.

Suatu penelitian tindakan kelas dikatakan berhasil apabila masingmasing indikator yang diukur telah mencapai target yang telah ditetapkan. Penelitian ini dapat dikatakan berhasil karena masing-masing indikator yang diukur telah mencapai target yang ditentukan. Berdasarkan hasil tindakan, pengamatan dan pembahasan dapat ditarik kesimpulan bahwa penerapan model pembelajrana POGIL dapat meningktakan keterampilan generik sains dan prestasi belajar siswa pada materi larutan penyangga kelas XI MIPA 4 SMA Negeri 5 Surakarta Tahun Pelajaran 2017/2018.

\section{KESIMPULAN}

Berdasarkan hasil penelitian, dapat disimpulkan bahwa penerapan model pembelajaran Process Oriented Guided Inquiry Learning (POGIL) dapat meningkatkan keterampilan generik sains $(71 \%$ pada siklus I dan meningkat menjadi $87 \%$ pada siklus II) dan prestasi belajar siswa (aspek pengetahuan dari $29 \%$ di siklus I menjadi $77 \%$ di siklus II; aspek sikap ketercapaian 100\% dimana $29 \%$ pada kategori Baik dan $71 \%$ pada kategori Sangat Baik dan aspek keterampilan ketercapaian siswa juga $100 \%$ dengan rata-rata ketercapaian indikator keterampilan sebesar $88,5 \%$ ) pada materi larutan penyangga siswa kelas XI MIPA 4 SMA Negeri 5 Surakarta tahun pelajaran 2017/2018.

\section{UCAPAN TERIMA KASIH}

Bapak Drs. Yusmar Setyobudi, M.M., M.Pd. selaku Kepala Sekolah SMA Negeri 5 Surakarta, yang telah memberikan izin guna pengambilan data serta Bapak Drs. Ari Harnanto, M.Si., selaku guru mata pelajaran kimia SMA Negeri 5 Surakarta yang telah memberi bantuan selama pelaksanaan penelitian.

\section{DAFTAR RUJUKAN}

[1] Departemen Pendidikan Nasional., 2003, Undang-Undang Nomor 20 Tahun 2003 tentang Sistem Pendidikan Nasional, Depdiknas, Jakarta.

[2] Rakhmawati, S., Muspiroh, N., \& Azmi, N., 2016, Jurnal Pendidikan Sains, 5(2), 156-164.

[3] Indraswari, R. A., Widodo, W., \& Muchlis, 2015, Jurnal Pendidikan IPA E-Pensa, 3(2). 
[4] Fajri, L., Ashadi, \& Utomo, S. B., 2015, Jurnal Inkuiri, 4(2), 10-18.

[5] Simonson, S. R., \& Shadle, S. E., 2013, Journal of STEM Education: Innovations and Research, 14(1), 56-63.

[6] Anam, K., 2015, Pembelajaran Berbasis Inkuiri Metode dan Aplikasi, Pustaka Pelajar, Yogyakarta.

[7] Marsita, R. A., Priatmoko, S., \& Kusuma, E., 2010, Jurnal Inovasi Pendidikan Kimia, 4(1), 512-520.

[8] Kurniawan, M. A., Prayitno, \& Yahmin., 2013, Menggali Pemahaman Siswa SMA Pada Konsep Larutan Penyangga Menggunakan Instrumen Diagnostik Two-Tier, Skripsi.

[9] Murti, M. M. S., 2014, Jurnal Pendidikan Kimia, 3(4), 75-82.

[10] Sudarmin, 2012, Keterampilan Generik Sains dan Penerapannya dalam Pembelajaran Kimia Organik, UNNES Press, Semarang.

[11] Mercer-mapstone, L.D., \& Kuchel, L.J., 2016, Teaching \& Learning Inquiry, 4(2). 1-14.

[12] Kusdiwelirawan, A., Hartini, T. I., \& Najihah, A. R., 2015, Jurnal Fisika Dan Pendidikan Fisika., 1(2). 19-23.
[13] Curtis, D., \& Denton, R., 2003, The authentic performance-based assessment of problem-solving generic skills NCVER, NCVER, Australia.

[14] Miles, M. B. \& Huberman, A. M., 1995, Analisis Data Kualitatif, Terj. Tjetjep Rohendi Rohidi, UI-Press, Jakarta.

[15] Suwandi, S., 2009, Penelitian Tindakan Kelas (PTK) dan Penulisan Karya Ilmiah, Mata Padi Presindo, Surakarta.

[16] Febriyanti, D., llyas, S., \& Nurmaliah, C., 2014, Jurnal Biologi Edukasi, 6(2), 43-47.

[17] Hande S, Mohammed C.A., and Komattil R., 2015, Journal of Taibah University Medical Sciences, 10(1), 21-25.

[18] Maulidiawati \& Soeprodjo, 2014, Chemistry in Education, 3 (2), 163169.

[19] Kori, K., Mäeots, M., \& Pedaste, M., 2014, Procedia -Social and Behavioral Sciences, 112, 242-251.

[20] Şen, Ş., \& Yılmaz, A., 2015, Problems of Education in the 21st Century, 66(1), 54-66. 